\title{
Identifikasi kemampuan makroskopik, mikroskopik dan simbolik siswa kelas XI MIPA SMA Negeri 1 Karangan Trenggalek pada materi larutan penyangga Tahun Ajaran 2018/2019
}

\author{
Endah Yuliani, Hayuni Retno Widarti*, Darsono Sigit \\ Universitas Negeri Malang, Jl. Semarang No. 5 Malang, Jawa Timur, Indonesia \\ *Penulis korespondensi, Surel: hayuni.retno.fmipa@um.ac.id
}

Paper received: 01-06-2021; revised: 15-06-2021; accepted: 30-06-2021

\begin{abstract}
Abstrak
Penelitian ini bertujuan untuk mendeskripsikan: (1) Kemampuan makroskopik-mikroskopik, makroskopik-simbolik dan mikroskopik-simbolik siswa kelas XI MIPA SMA Negeri 1 Karangan Trenggalek pada materi larutan penyangga (2) Kemampuan pemahaman siswa kelas XI MIPA SMA Negeri 1 Karangan Trenggalek terhadap materi larutan penyangga pada level makroskopikmikroskopik, makroskopik-simbolik dan mikroskopik-simbolik. Rancangan penelitian ini menggunakan rancangan deskriptif. Instrumen penelitian berupa soal-soal pilihan ganda berbasis interkoneksi multipel representasi. Hasil penelitian menunjukkan bahwa (1) kemampuan representasi makroskopik-mikroskopik siswa pada materi larutan penyangga sebesar 57,61 persen (kriteria cukup), (2) kemampuan representasi makroskopik-simbolik siswa pada materi larutan penyangga sebesar 66,67 persen (kriteria tinggi), (3) kemampuan representasi mikroskopiksimbolik siswa pada materi larutan penyangga sebesar 55,61 persen (kriteria cukup), (4) kemampuan pemahaman siswa terhadap materi larutan penyangga pada representasi makroskopik-mikroskopik yaitu miskonsepsi sebesar 27,20 persen dan tidak paham sebesar 18,56 persen, (5) kemampuan pemahaman siswa terhadap materi larutan penyangga pada representasi makroskopik-simbolik yaitu miskonsepsi sebesar 13,62 persen dan tidak paham sebesar 20,69 persen dan (6) kemampuan pemahaman siswa terhadap materi larutan penyangga pada representasi mikroskopik-simbolik yaitu miskonsepsi sebesar 37,36 persen dan tidak paham sebesar 19,82 persen.
\end{abstract}

Kata Kunci: Kemampuan representasi; makroskopik; mikroskopik; simbolik; larutan penyangga.

\section{Pendahuluan}

Ilmu kimia merupakan bagian dari ilmu pengetahuan alam (sains) yang dianggap sulit oleh siswa. Hal ini terjadi karena karakteristik ilmu kimia yang bersifat abstrak dan kompleks. Selain itu, mata pelajaran kimia juga dipenuhi dengan rumus-rumus, simbolsimbol, reaksi-reaksi, dan konsep-konsep yang dianggap abstrak oleh siswa (Ashadi, 2009). Untuk mempelajari ilmu kimia yang bersifat abstrak diperlukan suatu penggambaran yang dijelaskan oleh para ahli ke dalam tiga level representasi, yaitu representasi makroskopik, mikroskopik dan simbolik (Indrayani, 2013).

Representasi makroskopik merupakan level yang konkret, dimana pada level ini siswa dapat mengamati fenomena yang terjadi, baik melalui percobaan yang dilakukan atau fenomena yang terjadi pada kehidupan sehari-hari. Fenomena-fenomena yang dapat diamati berupa timbulnya warna, terbentuknya endapan dan gas dalam reaksi kimia. Representasi mikroskopik merupakan penggambaran partikel yang tidak dapat dilihat secara langsung, seperti atom, molekul dan ion. Representasi simbolik merupakan penggambaran dari fenomena kimia melalui persamaan kimia, persamaan matematika, grafik, mekanisme reaksi, dan analogi-analogi kimia (Chandrasegaran et al, 2008). Ketiga level representasi kimia 
tersebut saling berhubungan, meliputi hubungan level makroskopik-mikroskopik, makroskopik-simbolik dan mikroskopik-simbolik atau dapat dikenal dengan istilah interkoneksi multipel representasi.Pembelajaran dengan menerapkan interkoneksi multipel representasi dapat meningkatkan pemahaman siswa terhadap konsep-konsep kimia dan mengurangi kesalahan konsep siswa (Gilbert dan Treagust, 2009).

Sirhan (2007) menyatakan interaksi dan perbedaan antara multipel representasi (makroskopik, mikroskopik dan simbolik) merupakan karakteristik dalam pembelajaran kimia yang sangat penting dan diperlukan dalam memahami konsep-konsep kimia. Jika siswa merasa kesulitan pada satu level maka dapat mempengaruhi level lainnya pada representasi kimia. Kunci pokok dalam pemecahan masalah kimia, sebenarnya adalah pada kemampuan merepresentasikan fenomena kimia pada level mikroskopik (Treagust et al, 2003). Pengajaran yang melibatkan level mikroskopik akan membantu siswa membuat hubungan antara tiga level representasi dalam pembelajaran kimia, adanya penjelasan karakteristik level mikroskopik kepada siswa akan meningkatkan pemahaman siswa dan menyebabkan siswa cenderung dapat menghubungkan pengetahuannya pada dua atau tiga level representasi (Gabel, 1993).

Materi larutan penyangga merupakan materi larutan yang memuat ketiga level representasi dan dibangun atas konsep dasar asam basa, $p \mathrm{H}$ larutan, kesetimbangan kimia, dan stoikiometri. Larutan penyangga yang dapat dijelaskan dengan representasi makroskopik, mikroskopik dan simbolik yaitu komponen larutan penyangga asam. Representasi kimia pada level makroskopik ditunjukkan dengan warna larutan penyangga asam setelah ditetesi indikator metil orange, warna tersebut menunjukkan nilai $p \mathrm{H}$ larutan penyangga asam. Representasi mikroskopik dapat berupa penggambaran partikel-partikel di dalam larutan yang dapat menjelaskan kenapa dapat terjadi fenomena makroskopik demikian. Representasi simbolik dapat berupa persamaan reaksi dari larutan penyangga.

Penelitian tentang pemahaman pada larutan penyangga dengan menggunakan level representasi kimia sebelumnya pernah dilakukan oleh Yusria Izzatul Ulva (2016) terhadap siswa SMAN 3 Malang menunjukkan bahwa pemahaman larutan penyangga pada level makroskopik termasuk kriteria sangat tinggi $(88,11 \%)$, pemahaman larutan penyangga pada level mikroskopik termasuk kriteria sangat rendah $(18,01 \%)$ dan pemahaman konsep larutan penyangga pada level simbolik termasuk kriteria sedang $(52,99 \%)$.

Berdasarkan latar belakang yang telah dijelaskan, maka dapat dituliskkan tujuan penelitian sebagai berikut ini: (1) mendeskripsikan Kemampuan makroskopik-mikroskopik, makroskopik-simbolik dan mikroskopik-simbolik siswa kelas XI MIPA SMA Negeri 1 Karangan Trenggalek pada materi larutan penyangga (2) mendeskripsikan Kemampuan pemahaman siswa kelas XI MIPA SMA Negeri 1 Karangan Trenggalek terhadap materi larutan penyangga pada level makroskopik-mikroskopik, makroskopik-simbolik dan mikroskopiksimbolik.

\section{Metode}

Penelitian yang dilakukan merupakan penelitian deskriptif. Pada Penelitian ini tidak memberikan perlakuan khusus terhadap sampel, tetapi sampel telah mendapatkan perlakuan secara alami melalui proses belajar mengajar sebelumnya oleh guru kimia di sekolah yang menjadi tempat penelitian. Penelitian ini peneliti hanya melakukan pengukuran terhadap variabel yang ada, yaitu mengukur tingkat kemampuan siswa dan mendeskripsikan penyebab 
kesalahan pemahaman siswa pada representasi makroskopik-mikroskopik, makroskopiksimbolik dan mikroskopik-simbolik pada materi larutan penyangga. Subjek penelitian yaitu siswa kelas XI MIPA 1 dan XI MIPA 2 sebanyak 57 siswa yang dipilih secara purposive sampling. Instrumen yang digunakan dalam penelitian ini adalah tes objektif berbasis interkoneksi multipel representasi menggunakan empat item jawaban disertai pemberian alasan terbuka yang telah dikembangkan oleh Sofia Nur Fadhilah (2018). Instrumen penelitian memiliki validitas $96,8 \%$ (kriteria sangat tinggi) dengan reliabilitas sebesar 0,922 (kriteria sangat tinggi).

Data yang diperoleh dalam penelitian berasal dari tes objektif disertai alasan terbuka siswa dan wawncara tidak terstruktur yang dilakukan pada dua siswa yang menjawab salah untuk mengidentifikasi kesulitan mereka terhadap konsep kimia dan dua siswa yang menjawab benar untuk mengidentifikasi apakah mereka benar-benar memahami konsep kimia yang diujikan.

Analisis data pada penelitian ini dilakukan dengan tahap-tahap: (1) memeberikan Skor Tes Pemahaman (2) mengelompokan Butir Soal Berdasarkan Kisi-kisi (3) Menghitung Persentase Jumlah Siswa yang Menjawab Benar Tiap Butir Soal pada Masing-Masing Representasi (4) Menghitung Rata-rata Persentase Jumlah Siswa yang Menjawab Benar pada Masing-Masing Representasi (5) Menganalisis Penyebab Kesalahan Siswa.

\section{Hasil dan Pembahasan}

\subsection{HASIL}

Berdasarkan jawaban tes objektif dan alasan terbuka siswa disajikan hasil analisis data berupa persentase jumlah siswa yang menjawab benar dan distribusi dugaan penyebab kesalahan siswa pada materi larutan penyangga pada representasi makroskopik-mikroskopik, makroskopik-simbolik dan mikroskopik-simbolik sebagai berikut.

\subsubsection{Kemampuan Siswa Terhadap Representasi Makroskopik-Mikroskopik}

Persentase jumlah siswa yang menjawab benar pada soal larutan penyangga representasi makroskopik-mikroskopik disajikan pada Tabel 4.1

Tabel 4.1 Persentase Jumlah Siswa Yang Menjawab Benar Pada Materi Larutan Penyangga Untuk Representasi Makroskopik-Mikroskopik

\begin{tabular}{lllll} 
& \multirow{2}{*}{$\begin{array}{l}\text { Nomor } \\
\text { sndikator soal }\end{array}$} & \multicolumn{2}{c}{$\begin{array}{l}\text { Siswa yang } \\
\text { menjawab benar }\end{array}$} & \multirow{2}{*}{ kriteria } \\
\cline { 3 - 4 } & & & & \\
\hline $\begin{array}{l}\text { Siswa dapat mengidentifikasi } \\
\text { jenis larutan penyangga asam }\end{array}$ & & & & \\
$\begin{array}{l}\text { dan perubahan warna kertas } \\
\text { lakmus, jika diberikan }\end{array}$ & 7 & 34 & $56,62 \%$ & Cukup \\
$\begin{array}{l}\text { gambaran submikroskopik } \\
\text { komponennya }\end{array}$ & & & \\
$\begin{array}{l}\text { Rata-rata } \\
\text { Komponen larutan penyangga }\end{array}$ & & $58,62 \%$ & Cukup
\end{tabular}


Siswa dapat menentukan

gambar submikroskopik larutan penyangga basa, jika diberikan gambaran ilustrasi pembuatan larutan

penyangga basa

Siswa dapat menentukan gambar submikroskopik larutan penyangga asam, jika diberikan gambaran ilustrasi 4 35 $60,34 \%$ Cukup pembuatan larutan penyangga asam.

\section{Rata-rata}

$60,34 \%$

Cukup

\section{Prinsip kerja larutan} penyangga

Siswa dapat menganalisis gambaran submikroskopik partikel larutan penyangga basa sebelum penambahan dan setelah penambahan

sedikit basa kuat

Siswa dapat menganalisis gambaran submikroskopik partikel larutan penyangga basa sebelum penambahan

sedikit asam kuat

Siswa dapat menganalisis gambaran submikroskopik partikel larutan penyangga asam sebelum dan setelah penambahan sedikit basa kuat

Siswa dapat menganalisis gambaran submikroskopik partikel larutan penyangga asam sebelum dan setelah penambahan sedikit asam kuat

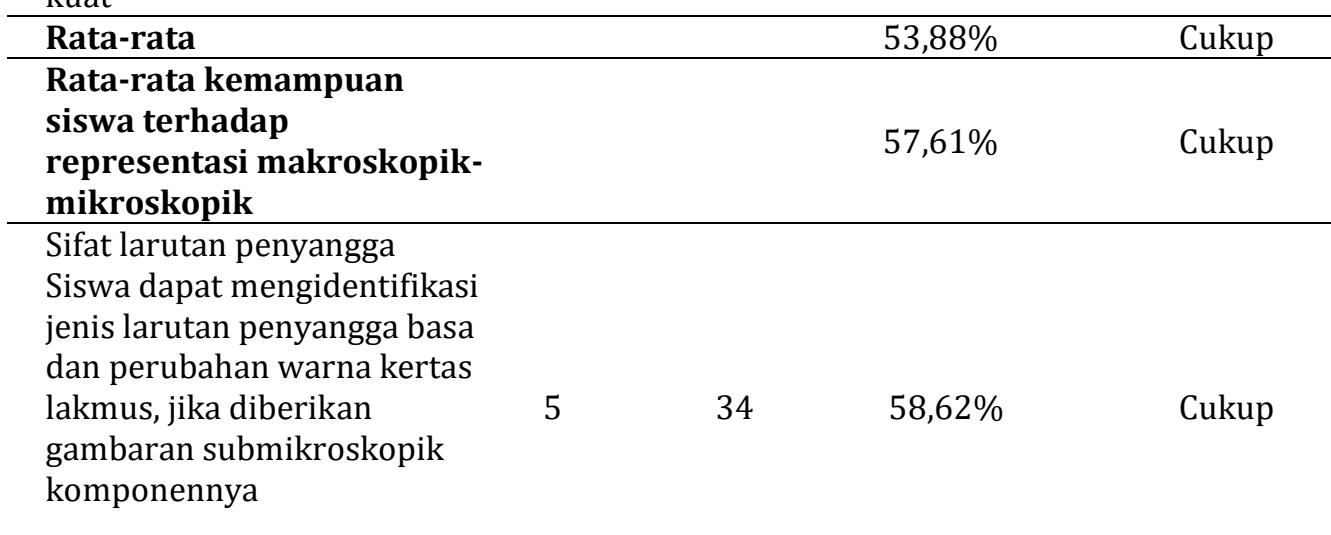

*Kriteria berdasarkan: Arikunto (2015:89) 
Berdasarkan data yang terdapat dalam Tabel 4.1, dapat diketahui bahwa ratarata siswa yang menjawab benar dari 8 soal larutan penyangga pada representasi makroskopik-mikroskopik sebesar 57,61\% termasuk kriteria cukup. Distribusi dugaan kesalahan siswa pada pada materi larutan penyangga untuk representasi makroskopik-mikroskopik disajikan pada Tabel 4.2

Tabel 4.2 Distribusi Dugaan Kesalahan Siswa Pada Pada Materi Larutan Penyangga untuk Representasi Makroskopik-Mikroskopik

\begin{tabular}{|c|c|c|c|}
\hline No. Soal & Dugaan Penyebab Kesalahan & $\begin{array}{l}\sum_{\text {Siswa }} \\
\end{array}$ & $\%$ \\
\hline \multirow{3}{*}{2.} & $\begin{array}{l}\text { siswa menganggap garam } \mathrm{NH}_{4} \mathrm{Cl} \text { terdisosiasi } \\
\text { sebagian di dalam air (tidak paham) }\end{array}$ & 6 & $10,34 \%$ \\
\hline & $\begin{array}{l}\text { - siswa menganggap } \mathrm{NH}_{3} \text { terionisasi secara } \\
\text { sempurna di dalam air (tidak paham) }\end{array}$ & 12 & $20,69 \%$ \\
\hline & $\begin{array}{l}\text { - siswa menganggap } \mathrm{NH}_{3} \text { termasuk asam lemah } \\
\text { (miskonsepsi) }\end{array}$ & 5 & $8,62 \%$ \\
\hline \multirow{3}{*}{4.} & $\begin{array}{l}\text { siswa menganggap garam } \mathrm{CH}_{3} \mathrm{COONa} \text { terdisosiasi } \\
\text { sebagian didalam air (tidak paham) }\end{array}$ & 7 & $12,07 \%$ \\
\hline & $\begin{array}{l}\text { siswa menganggap } \mathrm{CH}_{3} \mathrm{COOH} \text { terionisasi secara } \\
\text { sempurna di dalam air (tidak paham) }\end{array}$ & 11 & $18,97 \%$ \\
\hline & $\begin{array}{l}\text { siswa menganggap } \mathrm{CH}_{3} \mathrm{COOH} \text { adalah basa lemah } \\
\text { (miskonsepsi) }\end{array}$ & 5 & $8,62 \%$ \\
\hline \multirow{4}{*}{5.} & $\begin{array}{l}\text { siswa menganggap larutan yang terdiri dari basa } \\
\text { lemah } \mathrm{NH}_{3} \text { dan asam konjugasi dari garam } \mathrm{NH}_{4} \mathrm{Cl} \\
\text { merupakan larutan penyangga asam yang bisa } \\
\text { merubah kertas lakmus merah menjadi merah dan } \\
\text { dari biru ke merah (tidak paham) } \\
\text { siswa menganggap larutan yang terdiri dari basa } \\
\text { lemah } \mathrm{NH}_{3} \text { dan asam konjugasi dari garam } \mathrm{NH}_{4} \mathrm{Cl}\end{array}$ & 3 & $5,17 \%$ \\
\hline & $\begin{array}{l}\text { merupakan larutan basa yang bisa merubah kertas } \\
\text { lakmus merah menjadi biru dan dari biru ke biru } \\
\text { (tidak paham) } \\
\text { siswa menganggap larutan yang terdapat dalam }\end{array}$ & 7 & $12,07 \%$ \\
\hline & $\begin{array}{l}\text { gelas kimia merupakan larutan penyangga basa } \\
\text { karena adanya ion } \mathrm{OH}^{-} \text {dan garam } \mathrm{NH}_{4} \mathrm{Cl} \\
\text { (miskonsepsi) }\end{array}$ & 14 & $24,14 \%$ \\
\hline & $\begin{array}{l}\text { siswa menganggap larutan yang terdiri dari asam } \\
\text { lemah } \mathrm{CH}_{3} \mathrm{COOH} \text { dan basa konjugasi dari garam }\end{array}$ & & \\
\hline \multirow{3}{*}{7.} & $\begin{array}{l}\mathrm{CH}_{3} \mathrm{COONa} \text { merupakan larutan penyangga basa } \\
\text { yang bisa merubah kertas lakmus merah menjadi } \\
\text { biru dan dari biru ke biru (tidak paham) } \\
\text { siswa menganggap larutan yang terdiri dari asam } \\
\text { lemah } \mathrm{CH}_{3} \mathrm{COOH} \text { dan basa konjugasi dari garam }\end{array}$ & 1 & $1,72 \%$ \\
\hline & $\begin{array}{l}\mathrm{CH}_{3} \mathrm{COONa} \text { merupakan larutan asam yang bisa } \\
\text { merubah kertas lakmus merah menjadi merah dan } \\
\text { dari merah menjadi merah (tidak paham) } \\
\text { siswa menganggap larutan yang terdapat dalam }\end{array}$ & 2 & $3,45 \%$ \\
\hline & $\begin{array}{l}\text { gelas kimia merupakan larutan penyangga asam } \\
\text { karena ada ion } \mathrm{F}^{-}, \mathrm{H}^{+} \text {dan garam (miskonsepsi) }\end{array}$ & 21 & $36,21 \%$ \\
\hline 13. & $\begin{array}{l}\text { Siswa menganggap } \mathrm{NH}_{3} \text { akan terionisasi sempurna } \\
\text { di dalam air, sementara garam amonium klorida } \\
\text { akan terdisosiasi sebagian di dalam air dan }\end{array}$ & 19 & $32,76 \%$ \\
\hline
\end{tabular}
penambahan sedikit basa kuat akan meningkatkan 
$\left[\mathrm{OH}^{-}\right]$tetapi jumlah molekul $\mathrm{NH}_{3}$ dan ion $\mathrm{NH}_{4}$ tetap (tidak paham)

siswa menganggap $\mathrm{NH}_{3}$ termasuk asam lemah

(miskonsepsi)

Siswa menganggap $\mathrm{NH}_{3}$ akan terionisasi sempurna di dalam air, sementara garam amonium klorida

14. akan terdisosiasi sebagian di dalam air dan penambahan sedikit asam kuat akan menurunkan

[OH] tetapi jumlah molekul $\mathrm{NH}_{3}$ dan ion $\mathrm{NH}_{4}$ tetap (tidak paham)

siswa menganggap $\mathrm{NH}_{3}$ termasuk asam lemah (miskonsepsi)

Siswa menganggap $\mathrm{CH}_{3} \mathrm{COOH}$ akan terionisasi sempurna dalam air, sementara garam $\mathrm{CH}_{3} \mathrm{COONa}$

15. akan terdisosiasi sebagian dalam air dan penambahan sedikit basa kuat akan menurunkan

$\left[\mathrm{H}^{+}\right]$tetapi jumlah molekul $\mathrm{CH}_{3} \mathrm{COOH}$ dan ion $\mathrm{CH}_{3} \mathrm{COO}^{-}$tetap. (tidak paham)

siswa menganggap $\mathrm{CH}_{3} \mathrm{COOH}$ merupakan basa lemah (miskonsepsi)

Siswa menganggap $\mathrm{CH}_{3} \mathrm{COOH}$ akan terionisasi sempurna dalam air, sementara garam $\mathrm{CH}_{3} \mathrm{COONa}$

16. akan terdisosiasi sebagian dalam air dan penambahan sedikit asam kuat akan meningkatkan $\left[\mathrm{H}^{+}\right]$tetapi jumlah molekul $\mathrm{CH}_{3} \mathrm{COOH}$ dan ion $\mathrm{CH}_{3} \mathrm{COO}^{-}$tetap (tidak paham) siswa menganggap $\mathrm{CH}_{3} \mathrm{COOH}$ merupakan basa lemah (miskonsepsi)

Keterangan :

Dugaan penyebab kesalahan diperoleh dari analisis jawaban dan alasan siswa satu per satu untuk mengetahui miskonsepsi dan pemahaman salah siswa *) dapat dilihat pada Tabel 3.2

\subsubsection{Kemampuan Siswa Terhadap Representasi Makroskopik-Simbolik}

Persentase jumlah siswa yang menjawab benar pada soal larutan penyangga representasi makroskopik-simbolik disajikan pada Tabel 4.3

Tabel 4.3 Persentase Jumlah Siswa Yang Menjawab Benar Pada Materi Larutan Penyangga Untuk Representasi Makroskopik-Simbolik

\begin{tabular}{|c|c|c|c|c|}
\hline \multirow[t]{2}{*}{ Indikator soal } & \multirow{2}{*}{$\begin{array}{l}\text { Nomor } \\
\text { soal }\end{array}$} & \multicolumn{2}{|c|}{$\begin{array}{l}\sum_{\text {menjawab benar }} \text { siswa yang } \\
\text { meab ben }\end{array}$} & \multirow[t]{2}{*}{ Kriteria } \\
\hline & & Jumlah & Persentase (\%) & \\
\hline $\begin{array}{l}\text { Sifat larutan penyangga } \\
\text { Siswa dapat mengidentifikasi } \\
\text { jenis larutan penyangga basa } \\
\text { dan daerah } p H \text { yang dimiliki } \\
\text { larutan, jika diberikan data } \\
\text { persamaan reaksi } \\
\text { kesetimbangan dari larutan } \\
\text { basa lemah dengan garamnya }\end{array}$ & 9 & 43 & $74,14 \%$ & Tinggi \\
\hline $\begin{array}{l}\text { Sifat larutan penyangga } \\
\text { Siswa dapat mengidentifikasi } \\
\text { jenis larutan penyangga basa, } \\
p \mathrm{H} \text { awal dan } p \mathrm{H} \text { setelah }\end{array}$ & 17 & 41 & $70,69 \%$ & Tinggi \\
\hline
\end{tabular}


penambahan asam maupun basa serta perubahan warna kertas lakmus suatu larutan, jika diberikan data persamaan reaksi dari larutan basa lemah dengan garamnya.

Siswa dapat mengidentifikasi jenis larutan penyangga asam, $p \mathrm{H}$ awal dan $p \mathrm{H}$ setelah penambahan asam maupun basa serta perubahan warna

kertas lakmus suatu larutan, jika diberikan data persamaan reaksi dari larutan asam lemah dengan garamnya.

\section{Rata- rata}

$71,56 \%$

Tinggi

Komponen larutan penyangga Siswa dapat menentukan persamaan reaksi kesetimbangan yang tepat untuk larutan penyangga basa, jika diberikan gambaran gambaran ilustrasi pembuatan larutan penyangga basa.

Siswa dapat menentukan persamaan reaksi kesetimbangan yang tepat untuk larutan penyangga asam jika diberikan gambaran ilustrasi pembuatan larutan penyangga asam.

\section{Rata-rata}

pH larutan penyangga Siswa dapat menghitung $p \mathrm{H}$ larutan penyangga basa sebelum penambahan basa kuat dan setelah penambahan basa kuat, jika diberikan data konsentrasi masing-masing komponen penyusun, Ka asam lemah serta volume larutan penyangga asam

Siswa dapat menghitung $p \mathrm{H}$ larutan penyangga basa sebelum penambahan asam kuat dan setelah penambahan asam kuat, jika diberikan data konsentrasi masing-masing komponen penyusun, Ka asam lemah serta volume larutan penyangga asam $\mathrm{pH}$ larutan penyangga Siswa dapat menghitung $p \mathrm{H}$ 
larutan penyangga asam sebelum penambahan basa kuat dan setelah penambahan basa kuat, jika diberikan data konsentrasi masing-masing komponen penyusun, Ka asam lemah serta volume larutan penyangga asam Siswa dapat menghitung $p \mathrm{H}$ larutan penyangga asam sebelum penambahan asam kuat dan setelah penambahan asam kuat, jika diberikan data konsentrasi masing-masing $\begin{array}{llll}28 & 38 & 65,51 \% & \text { Tinggi }\end{array}$ komponen penyusun, Ka asam lemah serta volume larutan penyangga asam

Rata- rata

Rata-rata kemampuan siswa terhadap representasi makroskopik-simbolik

*Kriteria berdasarkan: Arikunto (2015:89)

Berdasarkan data yang terdapat dalam Tabel 4.3, dapat diketahui bahwa ratarata siswa yang menjawab benar dari 10 soal larutan penyangga pada representasi makroskopik-simbolik sebesar 66,67\% termasuk kriteria tinggi. Distribusi dugaan kesalahan siswa pada pada materi larutan penyangga untuk representasi makroskopik-simbolik disajikan pada Tabel 4.4

Tabel 4.4 Distribusi Dugaan Kesalahan Siswa Pada Pada Materi Larutan Penyangga Untuk Representasi Makroskopik-Simbolik

\begin{tabular}{|c|c|c|c|}
\hline $\begin{array}{l}\text { No. } \\
\text { Soal }\end{array}$ & Dugaan Penyebab Kesalahan & $\begin{array}{l}\sum \\
\text { Sis } \\
\text { wa }\end{array}$ & $\%$ \\
\hline 9. & $\begin{array}{l}\text { siswa menganggap persamaan reaksi kesetimbangan } \\
\text { basa lemah } \mathrm{N}_{2} \mathrm{H}_{4} \text { dan garam } \mathrm{N}_{2} \mathrm{H}_{5} \mathrm{Cl} \text { merupakan larutan } \\
\text { basa karena terdapat ion } \mathrm{OH}^{-}(\text {tidak paham) } \\
\text { siswa menganggap persamaan reaksi kesetimbangan } \\
\text { basa lemah } \mathrm{N}_{2} \mathrm{H}_{4} \text { dan garam } \mathrm{N}_{2} \mathrm{H}_{5} \mathrm{Cl} \text { merupakan larutan } \\
\text { penyangga basa karena terdapat } \mathrm{OH}^{-} \text {dan garam } \\
\mathrm{N}_{2} \mathrm{H}_{5} \mathrm{Cl} \text { (miskonsepsi) }\end{array}$ & 10 & $17,24 \%$ \\
\hline 11. & $\begin{array}{l}\text { siswa menganggap persamaan reaksi kesetimbangan } \\
\text { asam lemah } \mathrm{HF} \text { dan garam } \mathrm{NaF} \text { merupakan larutan } \\
\text { asam karena terdapat ion } \mathrm{H}^{+} \text {(tidak paham) } \\
\text { siswa menganggap persamaan reaksi kesetimbangan } \\
\text { asam lemah } \mathrm{HF} \text { dan garam } \mathrm{NaF} \text { merupakan larutan } \\
\text { penyangga asam karena terdapat } \mathrm{H}^{+} \text {dan garam } \mathrm{NaF} \\
\text { (miskonsepsi) }\end{array}$ & 12 & $20,69 \%$ \\
\hline 17. & $\begin{array}{l}\text { siswa menganggap persamaan reaksi kesetimbangan } \\
\text { basa lemah } \mathrm{C}_{6} \mathrm{H}_{5} \mathrm{NH}_{2} \text { dan garam } \mathrm{C}_{6} \mathrm{H}_{5} \mathrm{NH}_{3} \mathrm{Cl} \text { merupakan } \\
\text { larutan basa karena terdapat } \mathrm{OH}^{-} \text {(tidak paham) } \\
\text { siswa menganggap persamaan reaksi kesetimbangan }\end{array}$ & 5 & $\begin{array}{l}8,62 \% \\
20,69 \%\end{array}$ \\
\hline
\end{tabular}


basa lemah $\mathrm{C}_{6} \mathrm{H}_{5} \mathrm{NH}_{2}$ dan garam $\mathrm{C}_{6} \mathrm{H}_{5} \mathrm{NH}_{3} \mathrm{Cl}$ merupakan larutan penyangga basa karena terdapat $\mathrm{OH}^{-}$dan garam $\mathrm{C}_{6} \mathrm{H}_{5} \mathrm{NH}_{3} \mathrm{Cl}$ (miskonsepsi)

siswa menganggap persamaan reaksi kesetimbangan

20. asam lemah $\mathrm{H}_{2} \mathrm{CO}_{3}$ dan garam $\mathrm{NaHCO}_{3}$ merupakan larutan asam karena terdapat ion $\mathrm{H}^{+}$(tidak paham) siswa menganggap persamaan reaksi kesetimbangan asam lemah $\mathrm{H}_{2} \mathrm{CO}_{3}$ dan garam $\mathrm{NaHCO}_{3}$ merupakan larutan penyangga asam karena terdapat ion $\mathrm{H}^{+}$dan garam $\mathrm{NaHCO}_{3}$ (miskonsepsi)

1. Siswa menganggap garam $\mathrm{NH}_{4} \mathrm{Cl}$ reaksinya bolak-balik dan basa lemah $\mathrm{NH}_{3}$ reaksinya searah (tidak paham)

Siswa menganggap basa lemah $\mathrm{NH}_{3}$ sebagai asam lemah yang reakinya bolak-balik (miskonsepsi)

Siswa menganggap garam $\mathrm{CH}_{3} \mathrm{COONa}$ reaksinya bolak-

3. balik dan asam lemah $\mathrm{CH}_{3} \mathrm{COOH}$ reaksinya searah

(tidak paham)

Siswa menganggap $\mathrm{CH}_{3} \mathrm{COOH}$ basa lemah yang

reaksinya bolak-balik (miskonsepsi)

Siswa menganggap bahwa $\left[\mathrm{OH}^{-}\right]$dihitung atas dasar

25. perbandingan konsentrasi a basa lemah dengan garam (miskonsepsi)

Siswa tidak bisa menghitung $\mathrm{pH}$ larutan penyangga basa setelah penambahan sedikit basa kuat (tidak paham)

Siswa menganggap bahwa [0H-] dihitung atas dasar

26. perbandingan konsentrasi basa lemah dengan garam (miskonsepsi)

Siswa tidak bisa menghitung $\mathrm{pH}$ larutan penyangga basa setelah penambahan sedikit asam kuat (tidak paham)

Siswa menganggap bahwa $\left[\mathrm{H}^{+}\right]$dihitung atas dasar

27. perbandingan konsentrasi asam lemah dengan garam (miskonsepsi)

Siswa tidak bisa menghitung $\mathrm{pH}$ larutan penyangga asam setelah penambahan sedikit basa kuat (tidak paham)

Siswa menganggap bahwa $\left[\mathrm{H}^{+}\right]$dihitung atas dasar

28. perbandingan konsentrasi asam lemah dengan garam (miskonsepsi)

Siswa tidak bisa menghitung $\mathrm{pH}$ larutan penyangga asam setelah penambahan sedikit asam kuat (tidak paham)

\section{Keterangan :}

Dugaan penyebab kesalahan diperoleh dari analisis jawaban dan alasan siswa satu per satu untuk mengetahui miskonsepsi dan pemahaman salah siswa

*) dapat dilihat pada Tabel 3.2 


\subsubsection{Kemampuan Siswa Terhadap Representasi Mikroskopik-Simbolik}

Persentase jumlah siswa yang menjawab benar pada soal larutan penyangga representasi mikroskopik-simbolik disajikan pada Tabel 4.5

Tabel 4.5 Persentase Jumlah Siswa Yang Menjawab Benar Pada Materi Larutan Penyangga Untuk Representasi Mikroskopik-Simbolik

\begin{tabular}{|c|c|c|c|c|}
\hline \multirow[t]{2}{*}{ Indikator soal } & \multirow{2}{*}{$\begin{array}{l}\text { Nomor } \\
\text { soal }\end{array}$} & \multicolumn{2}{|c|}{$\begin{array}{l}\sum \text { siswa yang } \\
\text { menjawab benar }\end{array}$} & \multirow[t]{2}{*}{ Kriteria } \\
\hline & & Jumlah & Persentase (\%) & \\
\hline $\begin{array}{l}\text { Komponen larutan penyangga } \\
\text { Siswa dapat menentukan } \\
\text { komponen (molekul dan ion) } \\
\text { dalam larutan penyangga basa, } \\
\text { jika diberikan data persamaan } \\
\text { reaksi kesetimbangan dari } \\
\text { larutan basa lemah dengan } \\
\text { garamnya }\end{array}$ & 10 & 29 & $50,00 \%$ & Cukup \\
\hline $\begin{array}{l}\text { Siswa dapat menentukan } \\
\text { komponen (molekul dan ion) } \\
\text { dalam larutan penyangga } \\
\text { asam, jika diberikan data } \\
\text { persamaan reaksi } \\
\text { kesetimbangan dari larutan } \\
\text { asam lemah dengan garamnya }\end{array}$ & 12 & 27 & $46,55 \%$ & Cukup \\
\hline $\begin{array}{l}\text { Siswa dapat mengidentifikasi } \\
\text { campuran larutan yang dapat } \\
\text { membentuk larutan } \\
\text { penyangga basa dari data } \\
\text { gambaran mikroskopik } \\
\text { partikel larutan penyangga } \\
\text { yang disedikan }\end{array}$ & 6 & 30 & $51,72 \%$ & Cukup \\
\hline $\begin{array}{l}\text { Siswa dapat mengidentifikasi } \\
\text { campuran larutan yang dapat } \\
\text { membentuk larutan } \\
\text { penyangga asam dari data } \\
\text { gambaran mikroskopik } \\
\text { partikel larutan penyangga } \\
\text { yang disedikan }\end{array}$ & 8 & 32 & $55,17 \% \%$ & Cukup \\
\hline Rata-rata & & & $50,86 \%$ & Cukup \\
\hline $\begin{array}{l}\text { Prinsip kerja larutan } \\
\text { penyangga } \\
\text { Siswa dapat menganalisis arah } \\
\text { pergeseran kesetimbangan } \\
\text { larutan penyangga basa } \\
\text { setelah ditambahkan sedikit } \\
\text { basa jika diberikan data } \\
\text { persamaan reaksi suatu } \\
\text { larutan penyangga basa }\end{array}$ & 18 & 25 & $43,10 \%$ & Cukup \\
\hline Siswa dapat menganalisis arah & 19 & 26 & $44,83 \%$ & Cukup \\
\hline
\end{tabular}


pergeseran kesetimbangan

larutan penyangga basa setelah ditambahkan sedikit asam, jika diberikan data persamaan reaksi suatu larutan penyangga basa

Prinsip kerja larutan penyangga

Siswa dapat menganalisis arah pergeseran kesetimbangan larutan penyangga asam setelah ditambahkan sedikit basa jika diberikan data

Cukup persamaan reaksi suatu larutan penyangga basa

Siswa dapat menganalisis arah pergeseran kesetimbangan larutan penyangga asam setelah ditambahkan sedikit asam jika diberikan data persamaan reaksi suatu larutan penyangga basa Rata-rata

Peran larutan penyangga Siswa dapat menuliskan persamaan reaksi kesetimbangan larutan penyangga pada sistem penyangga karbonat, jika diberikan pernyataan tentang penyangga karbonat.

Siswa dapat menuliskan persamaan reaksi kesetimbangan larutan penyangga pada sistem penyangga fosfat, jika diberikan pernyataan tentang penyangga fosfat.

\section{Rata-rata}

Rata-rata kemampuan siswa terhadap representasi mikroskopik-simbolik

48,71\% Cukup *Kriteria berdasarkan: Arikunto (2015:89)

Berdasarkan data yang terdapat dalam Tabel 4.5, dapat diketahui bahwa ratarata siswa yang menjawab benar dari 10 soal larutan penyangga pada representasi mikroskopik-simbolik sebesar 55,61\% termasuk kriteria cukup. Distribusi dugaan kesalahan siswa pada pada materi larutan penyangga untuk representasi mikroskopiksimbolik disajikan pada Tabel 4.6 
Tabel 4.6 Distribusi Dugaan Kesalahan Siswa Pada Pada Materi Larutan Penyangga Untuk Representasi Mikroskopik-Simbolik

\begin{tabular}{|c|c|c|c|}
\hline $\begin{array}{l}\text { No. } \\
\text { Soal }\end{array}$ & Dugaan Penyebab Kesalahan & $\begin{array}{l}\sum_{\text {Siswa }} \\
\end{array}$ & $\%$ \\
\hline 10. & $\begin{array}{l}\text { siswa menganggap garam } \mathrm{N}_{2} \mathrm{H}_{5} \mathrm{Cl} \text { tidak terdisosiasi } \\
\text { dan menganggap basa lemah } \mathrm{N}_{2} \mathrm{H}_{4} \text { terionisasi } \\
\text { sempurna (tidak paham) } \\
\text { siswa menganggap basa lemah } \mathrm{N}_{2} \mathrm{H}_{4} \text { tidak } \\
\text { terionisasi (miskonsepsi) }\end{array}$ & 21 & $13,80 \%$ \\
\hline 12. & $\begin{array}{l}\text { siswa menganggap HF terionisasi sempurna dan } \\
\text { garam NaF tidak terdisosiasi (tidak paham) } \\
\text { siswa menganggap HF tidak terionisasi } \\
\text { (miskonsepsi) }\end{array}$ & 10 & $17,24 \%$ \\
\hline 6. & $\begin{array}{l}\text { siswa menganggap larutan penyangga basa dapat } \\
\text { dibuat dengan mereaksikan basa lemah dengan } \\
\text { asam kuat berlebih (tidak paham) } \\
\text { siswa menganggap larutan penyangga basa dapat } \\
\text { dibuat dengan mereaksikan asam kuat dengan } \\
\text { garam (tidak paham) }\end{array}$ & 20 & $13,80 \%$ \\
\hline 8. & $\begin{array}{l}\text { siswa menganggap larutan penyangga asam dapat } \\
\text { dibuat dengan mereaksikan asam lemah dengan } \\
\text { basa kuat berlebih (tidak paham) } \\
\text { siswa menganggap larutan penyangga asam dapat } \\
\text { dibuat dengan mereaksikan basa kuat dengan } \\
\text { garam (tidak paham) }\end{array}$ & 17 & $29,31 \%$ \\
\hline 18. & $\begin{array}{l}\text { siswa menganggap penambahan sedikit basa pada } \\
\text { larutan penyangga basa akan menyebabkan ion } \\
\text { OH- bereaksi dengan molekul basa lemah dan } \\
\text { kesetimbangan bergeser ke kanan (tidak paham) } \\
\text { siswa menganggap penambahan sedikit basa kuat } \\
\text { pada larutan penyangga basa akan mengurangi } \\
\text { konsentrasi reaktan dan kesetimbangan bergeser } \\
\text { ke kiri (miskonsepsi) }\end{array}$ & 28 & $48,28 \%$ \\
\hline 19. & $\begin{array}{l}\text { siswa menganggap penambahan sedikit asam pada } \\
\text { larutan penyangga basa akan menyebabkan ion } \mathrm{H}^{+} \\
\text {bereaksi asam } \\
\text { konjugasi dan kesetimbangan bergeser ke kiri } \\
\text { (tidak paham) } \\
\text { siswa menganggap penambahan sedikit asam pada } \\
\text { larutan penyangga basa akan mengurangi } \\
\text { konsentrasi produk dan kesetimbangan bergeser } \\
\text { ke kanan (miskonsepsi) }\end{array}$ & 25 & $12,07 \%$ \\
\hline 21. & $\begin{array}{l}\text { siswa menganggap penambahan sedikit basa kuat } \\
\text { pada larutan penyangga asam akan menyebabkan } \\
\text { ion } \mathrm{OH}^{-} \text {bereaksi dengan basa konjugasi dan } \\
\text { kesetimbangan bergeser ke kiri (tidak paham) } \\
\text { siswa menganggap penambahan sedikit basa pada } \\
\text { larutan penyangga asam akan mengurangi } \\
\text { konsentrasi reaktan dan kesetimbangan bergeser }\end{array}$ & 20 & $13,80 \%$ \\
\hline
\end{tabular}


ke kiri (miskonsepsi)

siswa menganggap penambahan sedikit basa kuat pada larutan penyangga asam akan menyebabkan

22. ion $\mathrm{H}^{+}$bereaksi dengan basa lemah dan

kesetimbangan bergeser ke kiri (tidak paham)

siswa menganggap penambahan sedikit asam pada

larutan penyangga asam akan mengurangi

konsentrasi produk dan kesetimbangan bergeser

ke kiri (miskonsepsi)

siswa menganggap persamaan reaksi

23. kesetimbangan penyangga karbonat terdiri dari $\mathrm{CO}_{2}(\mathrm{~g})+\mathrm{H}_{2} \mathrm{O}(\mathrm{l}) \rightleftharpoons \mathrm{H}_{2} \mathrm{CO}_{3}(a q)$ (tidak paham)

siswa menganggap persamaan reaksi

24. kesetimbangan penyangga fosfat terdiri dari $\mathrm{HHb}^{+}$

$$
+\mathrm{O}_{2} \rightleftharpoons \mathrm{H}^{+}+\mathrm{HbO}_{2}(a q) \text { (tidak paham) }
$$

Keterangan :

Dugaan penyebab kesalahan diperoleh dari analisis jawaban dan alasan siswa satu per satu untuk mengetahui miskonsepsi dan pemahaman salah siswa

*) dapat dilihat pada Tabel 3.2

\subsection{PEMBAHASAN}

\subsubsection{Kemampuan Siswa Terhadap Representasi Makroskopik-Mikroskopik}

Pembahasan kemampuan representasi makroskopik-mikroskopik siswa merujuk pada hasil analisis data Tabel 4.1 dan 4.2. Berdasarkan data pada Tabel 4.1, dapat diketahui bahwa rata-rata siswa yang menjawab benar pada 8 soal representasi makroskopik-mikroskopik sebesar $57,61 \%$ termasuk persentase dalam kriteria cukup.

Kemampuan Representasi Makroskopik-Mikroskopik Siswa pada Konsep Sifat Larutan Penyangga

Sifat larutan penyangga diukur dengan menggunakan butir soal nomor 5 dan 7 dengan disajikan gambaran mikroskopik berupa partikel-partikel penyusun larutan penyangga, siswa dapat mengidentifikasi jenis larutan penyangga dan sifat larutannya, penyebab kesalahan karena siswa kurang memahami teori asam basa, jenis larutan asam basa (lemah atau kuat), ionisasi pada asam basa atau disosiasi pada garam dan kurangnya pemahaman siswa mengenai partikel-partikel penyusun larutan penyangga, sehinggga siwa mengalami kebingungan ketika harus merepresentasikan partikelpartikel penyusun larutan penyangga ke dalam representasi makroskopiknya. Hal tersebut terbukti setelah dilakukannya wawancara dengan beberapa siswa yang menjawab benar dan alasan salah. Ringkasan hasil wawancara soal nomor 5 tersebut disajikan sebagai berikut.

$P$ : "manakah jawaban yang paling tepat untuk soal nomor 5?"

$S$ : “yang D bu,"

$P$ : "mengapa kok $D$ "?

$S$ : "karena di dalam larutan tersebut ada ion $\mathrm{OH}^{-}$dan garam bu, jadi ya termasuk larutan penyangga basa." 


\subsubsection{Kemampuan Representasi Makroskopik-Mikroskopik Siswa pada Konsep Komponen Larutan Penyangga}

Komponen larutan penyangga diukur dengan menggunakan butir soal nomor 2 dan 4 dengan disajikan gambaran makroskopik pembuatan larutan penyangga, siswa dapat merepresentasikan ke dalam representasi mikroskopiknya yaitu partikelpartikel penyusun larutan penyangga, penyebab kesalahan karena siswa kurang memahami teori asam basa, jenis larutan asam basa (lemah atau kuat), konsep ionisasi asam/basa lemah atau disosiasi garam, sehinggga siwa mengalami kesulitan ketika harus merepresentasikan gambaran makroskopik pembuatan larutan penyangga ke dalam representasi mikroskopik yaitu partikel-partikel penyusun larutan penyangga. Hal tersebut terbukti setelah dilakukannya wawancara dengan beberapa siswa yang menjawab salah dan alasan salah. Ringkasan hasil wawancara pada soal nomor 2 tersebut disajikan sebagai berikut.

$P$ : "manakah jawaban yang paling tepat untuk soal nomor 2?"

$S$ : "yang C bu,"

$P$ : "mengapa kok C"?

$\mathrm{S}$ : "karena $\mathrm{NH}_{4} \mathrm{Cl}$ nanti akan terdisosiasi sebagian saja bu dan yang $\mathrm{NH}_{3}$ akan teronisasi sempurna jadi kan yang $\mathrm{NH}_{3}$ molekulnya habis bu menjadi ion-ion, sesuai jawaban $\mathrm{C}$ tidak ada gambar molekul $\mathrm{NH}_{3}$ lagi bu."

\subsubsection{Kemampuan Representasi Makroskopik-Mikroskopik Siswa pada Konsep Prinsip Kerja Larutan Penyangga}

Prinsip kerja larutan penyangga diukur dengan menggunakan butir soal 13, 14, 15 dan 16, dengan disajikan gambaran makroskopik pembuatan larutan penyangga yang ditambahkan sedikit asam/basa kuat siswa dapat merepresentasikan ke dalam gambaran mikroskopik berupa partikel-partikel penyusunnya, penyebab kesalahan karena siswa tidak paham terhadap materi sebelumnya yaitu teori asam basa, jenis larutan asam basa (lemah atau kuat), konsep ionisasi asam basa atau disosiasi garam dan reaksi kesetimbangan dengan benar.

Secara keseluruhan rata-rata persentase siswa yang menjawab benar, miskonsepsi dan tidak paham pada soal larutan penyangga aspek representasi makroskopik-mikroskopik dapat digambarkan dalam grafik yang disajikan pada Gambar 5.1.

Gambar 5.1 Persentase Jawaban Siswa yang Menjawab Benar, Miskonsepsi dan Tidak Paham pada Aspek Hubungan Representasi Makroskopik-Mikroskopik

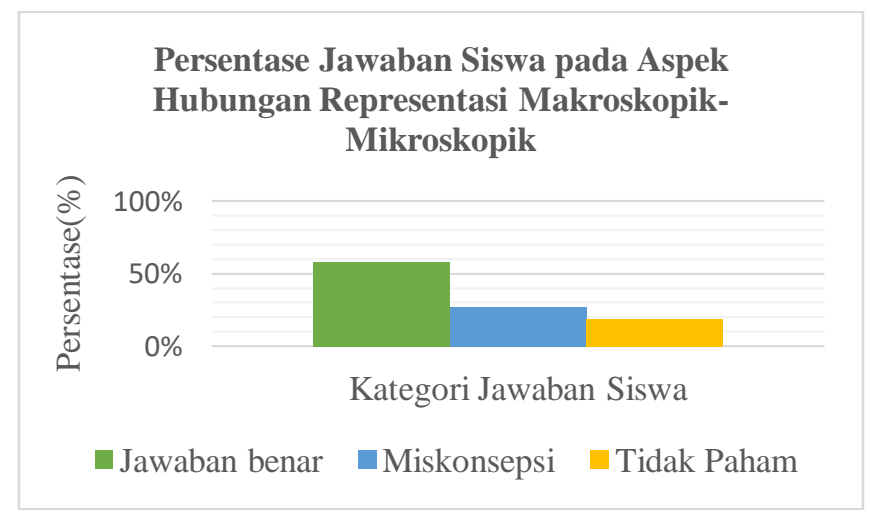




\subsubsection{Kemampuan Siswa Terhadap Representasi Makroskopik-Simbolik}

Pembahasan kemampuan representasi makroskopik-simbolik siswa merujuk pada hasil analisis data Tabel 4.3 dan 4.4. Berdasarkan data pada Tabel 4.3, dapat diketahui bahwa rata-rata siswa yang menjawab benar pada 10 soal representasi makroskopik-simbolik sebesar $66,67 \%$ termasuk persentase dalam kriteria tinggi.

\subsubsection{Kemampuan Representasi Makroskopik-Simbolik Siswa pada Konsep Sifat Larutan Penyangga}

Sifat larutan penyangga diukur dengan menggunakan soal nomor 9, 11, 17 dan 20, dengan disajikan persamaan reaksi kesetimbangan dari larutan penyangga siswa dapat mengidentifikasi jenis larutan penyangga disertai sifat larutan penyangga berupa daerah $p \mathrm{H}$ yang dimiliki larutan penyangga, $p \mathrm{H}$ awal dan $p \mathrm{H}$ setelah penambahan sedikit asam/basa serta perubahan warna pada kertas lakmus, penyebab kesalahan karena siswa kurang memahami teori asam basa, jenis larutan asam basa (lemah atau kuat), komponen penyusun larutan penyangga asam/basa sehingga siswa tidak paham dalam membedakan larutan asam, larutan basa, larutan penyangga basa dan larutan penyangga basa, selain itu siswa kurang memahami persamaan reaksi kesetimbangan. Hal tersebut terbukti setelah dilakukannya wawancara dengan beberapa siswa yang menjawab salah dan alasan salah. Ringkasan hasil wawancara terhadap soal nomor 9 tersebut disajikan sebagai berikut.

$P$ : "manakah jawaban yang paling tepat untuk soal nomor 9?"

$S$ : "yang $C$ bu,"

$P$ : "mengapa kok C"?

$S$ : "karena ada ion $\mathrm{OH}$, jadi ya larutan basa bu."

\subsubsection{Kemampuan Representasi Makroskopik-Simbolik Siswa pada Konsep Komponen Larutan Penyangga}

Komponen larutan penyangga diukur dengan menggunakan butir soal nomor 1 dan 3, dengan disajikan gambaran makroskopik pembuatan larutan penyangga, siswa dapat menentukan persamaan reaksi kesetimbangannya, penyebab kesalahan karena siswa belum memahami teori asam basa, jenis larutan asam basa (lemah atau kuat) dan kurangnya pemahaman siswa dalam memahami derajat ionisasi atau derajat disosiasi $(\alpha)$, dengan demikian siswa mengalami kesalahan dalam memahami reaksi ionisasi asam lemah atau basa lemah dan reaksi disosiasi garam. Berikut ringkasan wawancara peneliti dengan beberapa siswa yang menjawab salah pada nomer 3 .

$P$ : "manakah persamaan reaksi yang paling tepat dari ilustrasi gambar nomor 3?"

$S$ : "yang $A$ bu"

$P$ : "mengapa kok milih jawaban yang $A$ "

$S$ : "Menurut saya $\mathrm{CH}_{3} \mathrm{COONa}$ itu panah nya bolak-balik bu sedangkan yang $\mathrm{CH}_{3} \mathrm{COOH}$ lurus $b u$ ".

$P$ : "Mengapa $\mathrm{CH}_{3} \mathrm{COONa}$ itu panah nya bolak-balik sedangkan yang $\mathrm{CH}_{3} \mathrm{COOH}$ searah".

$S$ : "tidak tahu bu, tadi yang nomor 1 juga gitu bu". 


\subsubsection{Kemampuan Representasi Makroskopik-Simbolik Siswa pada Konsep $p H$ Larutan Penyangga}

Konsep $\mathrm{pH}$ larutan penyangga diukur dengan menggunakan butir soal nomor $25,26,27$ dan 28 , dengan disajikan gambaran makroskopik pembuatan larutan penyangga yang ditambahakan sedikit asam/basa kuat, siswa dapat menghitung $p \mathrm{H}$ larutan penyangga sebelum dan sesudah penambahan sedikit asam kuat/basa kuat, penyebab kesalahan karena ketidakmampuan siswa dalam menuliskan persamaan reaksi ketika larutan penyangga ditambahkan sedikit $\mathrm{HCl}$ dan $\mathrm{NaOH}$ dengan benar sehingga siswa tidak bisa menghitung jumlah mol larutan penyangga setelah penambahan $\mathrm{HCl}$ dan $\mathrm{NaOH}$ sehingga menyebabkan siswa tidak paham ketika harus menghitung $\mathrm{pH}$ penyangga setelah penambahan sedikit $\mathrm{HCl}$ dan $\mathrm{NaOH}$. Hal tersebut terbukti setelah dilakukannya wawancara dengan beberapa siswa yang menjawab benar dan alasan salah. Ringkasan hasil wawancara tersebut disajikan sebagai berikut.

$P$ : "manakah jawaban yang paling tepat untuk soal nomor 25?"

$S$ : “yang A bu,"

$P$ : "yang perhitungan $\mathrm{pH}$ setelah penambahan NaOH mana"?

$S$ : "tidak bisa menghitung bu."

Secara keseluruhan rata-rata persentase siswa yang menjawab benar, miskonsepsi dan tidak paham pada soal-soal larutan penyangga representasi makroskopik-simbolik dapat digambarkan dalam grafik yang disajikan pada Gambar 5.2.

\section{Gambar 5.2 Persentase Jawaban Siswa yang Menjawab Benar, Miskonsepsi dan Tidak Paham pada Aspek Hubungan Representasi Makroskopik-Simbolik}

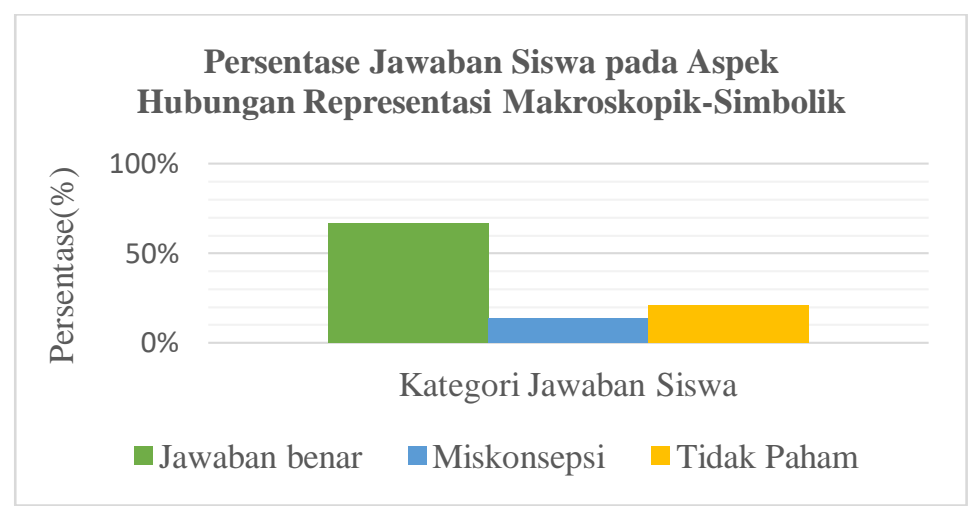

\subsubsection{Kemampuan Siswa Terhadap Representasi Mikroskopik-Simbolik}

Pembahasan kemampuan representasi mikroskopik-simbolik siswa merujuk pada hasil analisis data Tabel 4.5 dan 4.6. Berdasarkan data pada Tabel 4.5, dapat diketahui bahwa rata-rata siswa yang menjawab benar pada 10 soal representasi mikroskopik-simbolik sebesar 55,59\% yang termasuk persentase dalam kriteria cukup.

Kemampuan Representasi Mikroskopik-Simbolik Siswa pada Konsep Komponen Larutan Penyangga 
Komponen larutan penyangga diukur dengan butir soal nomor 6 dan 8 disajikan gambaran mikroskopik berupa partikel-partikel penyusun larutan penyangga, siswa harus mengidentifikasi campuran larutan yang dapat membentuk penyangga dari gambar yang disajikan, diukur dengan butir soal nomor 10 dan 12 disajikan persamaan reaksi kesetimbangan dari larutan penyangga, siswa dapat menentukan spesi-spesi penyusun larutan penyangganya, penyebab kesalahan karena siswa tidak memahami cara pembuatan larutan penyangga dan siswa kurang memahami teori asam basa, jenis larutan asam basa (lemah atau kuat), konsep ionisasi asam/basa lemah atau disosiasi garam. Berikut ringkasan wawancara peneliti dengan beberapa siswa yang menjawab salah pada nomor 6 .

P: "menurutmucampuran yang dapat membentuk larutan pada gambar mikroskopik ini yang mana?".

$S$ : "gambar itu kan larutan penyangga basa ya bu, karena ada $\mathrm{OH}^{-}$dan garam, berarti campurannya yang $A$ ".

$P$ : "mengapa bisa yang $A$ ".

$S$ : "itu kan ada $\mathrm{NaOH}$ bu dengan $\mathrm{NH}_{4} \mathrm{Cl}^{\text {". }}$

\subsubsection{Kemampuan Representasi Mikroskopik-Simbolik Siswa pada Konsep Prinsip Larutan Penyangga}

Prinsip larutan penyangga diukur menggunakan butir soal nomor 18, 19, 21 dan 22 , dengan disajikan persamaan reaksi kesetimbangan dari penyangga asam/basa, siswa dapat menganalisis prinsip kerja larutan penyangga setelah ditambahkan sedikit asam/basa kuat, penyebab kesalahan karena siswa tidak paham materi reaksi kesetimbangan kimia, sehingga siswa mengalami kebingungan untuk memahami pengaruh penambahan sedikit asam kuat ke dalam larutan penyangga basa dan bagaimana pergeseran kesetimbangannya. Hal tersebut terbukti setelah dilakukannya wawancara dengan beberapa siswa yang menjawab benar dan alasan salah. Ringkasan hasil wawancara tersebut disajikan sebagai berikut.

$P$ : "manakah jawaban yang paling tepat untuk soal nomor 18?"

$S$ : “yang A bu"

$P$ : "mengapa kok A"?

$S$ : "karena penyangga basa ditambah sedikit basa kan reaktannya berkurang, kesetimbangan bergeser ke yang kurang ke kiri bu".

\subsubsection{Kemampuan Representasi Mikroskopik-Simbolik Siswa pada Konsep Peran Larutan Penyangga}

Peran larutan penyangga dalam kehidupan sehari-hari diukur menggunakan butir soal nomor 23 dan 24 dengan disajikan pernyataan mikroskopik dari sistem penyangga karbonat dan fosfat siswa dapat menuliskan persamaan reaksinya.

Secara keseluruhan rata-rata persentase siswa yang menjawab benar, miskonsepsi dan tidak paham pada soal-soal larutan penyangga representasi mikroskopik-simbolik dapat digambarkan dalam grafik yang disajikan pada Gambar 5.3. 


\section{Gambar 5.3 Persentase Jawaban Siswa yang Menjawab Benar, Miskonsepsi dan Tidak Paham pada Aspek Hubungan Representasi Mikroskopik-Simbolik.}

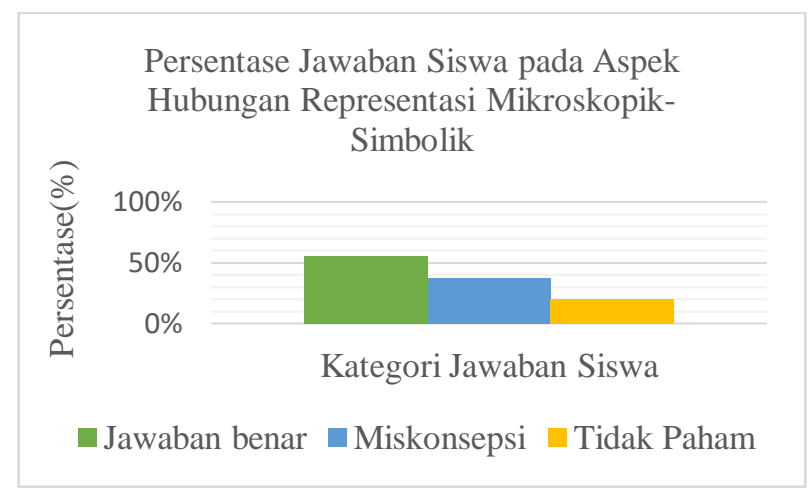

\section{Simpulan}

Berdasarkan hasil penelitian dan pembahasan yang telah dilakukan, maka dapat ditarik kesimpulan sebagai berikut: bahwa (1) kemampuan representasi makroskopikmikroskopik siswa pada materi larutan penyangga sebesar 57,61\% (kriteria cukup), (2) kemampuan representasi makroskopik-simbolik siswa pada materi larutan penyangga sebesar 66,67\% (kriteria tinggi), (3) kemampuan representasi mikroskopik-simbolik siswa pada materi larutan penyangga sebesar 55,61\% (kriteria cukup), (4) kemampuan pemahaman siswa terhadap materi larutan penyangga pada representasi makroskopikmikroskopik yaitu miskonsepsi sebesar 27,20\% dan tidak paham sebesar 18,56\%, (5) kemampuan pemahaman siswa terhadap materi larutan penyangga pada representasi makroskopik-simbolik yaitu miskonsepsi sebesar 13,62\% dan tidak paham sebesar 20,69\% dan (6) kemampuan pemahaman siswa terhadap materi larutan penyangga pada representasi mikroskopik-simbolik yaitu miskonsepsi sebesar 37,36\% dan tidak paham sebesar $19,82 \%$.

\section{Ucapan Terima Kasih}

Penulis menyadari penelitian ini tidak sempurna bantuan dan bimbingan dari berbagai pihak. Oleh karena itu penulis mengucapkan terima kasih kepada mengucapkan terima kasih kepada :

(1) Dr. Hj. Hayuni Retno Widarti, M.Si selaku dosen pembimbing I dan Drs. Darsono Sigit, M.Pd selaku dosen pembimbing II yang dengan sabar memberikan bimbingan dan saran selama proses penyusunan skripsi, sehingga skripsi ini bisa terselesaikan dengan baik,

(2) Dr. H. Mahmudi, M. Si selaku dosen penguji yang memberikan masukan berupa saran dan kritik dalam penyusunan skrispsi ini.

\section{Daftar Rujukan}

Chandrasegaran, A. L., Treagust, D. F., \& Mocerino, M. (2008). An evaluation of a teaching intervention to promote students' ability to use multiple levels of representation when describing and explaining chemical reactions. Research in Science Education, 38(2), 237-248.

Gabel, D. (1999). Improving teaching and learning through chemistry education research: A look to the future. Journal of Chemical education, 76(4), 548.

Gilbert, J. K. (2009). Multiple representations in chemical education (Vol. 4, pp. 4-6). D. Treagust (Ed.). Dordrecht: Springer. 
Indrayani, P. (2012). Analisis Pemahaman Makroskopik, Mikroskopik dan Simbolik Titrasi Asam-Basa Siswa Kelas XI IPA SMA serta Upaya Perbaikannya Dengan Pendekatan Mikroskopik.(Tesis). DISERTASI dan TESIS Program Pascasarjana UM.

Sirhan, G. (2007). Learning difficulties in chemistry: An overview. Journal of Turkish Science Education, 4 (2):2-20.

Treagust, D., Chittleborough, G., \& Mamiala, T. (2003). The role of submicroscopic and symbolic representations in chemical explanations. International journal of science education, 25(11), 13531368. 